\title{
ANALYSIS OF DL- $\alpha$-TOCOPHEROL AS ANTIOXIDANT ON MALONDIALDEHYDE LEVEL IN PEDIATRIC PATIENTS WITH $\beta$-THALASSEMIA MAJOR
}

\author{
Levana Rismayanti ${ }^{1}$, Yulistiani ${ }^{1}$, Mia Ratwita Andarsini ${ }^{2}$, Mariyatul Qibtiyah $^{3}$ \\ ${ }^{1}$ Department of Clinical Pharmacy, Airlangga University, Surabaya, ${ }^{2}$ Department of Pediatric Haematology, \\ Dr. Soetomo Hospital, Surabaya, 3Department of Pharmacy, Dr. Soetomo Hospital, Surabaya
}

\begin{abstract}
ABSTRAK
Talasemia merupakan bentuk anemia herediter yang mempengaruhi sintesis hemoglobin. Penatalaksanaan terapi pada pasien $\beta$ talasemia mayor yaitu pasien harus menerima transfusi darah terus menerus dan peningkatan absorpsi besi dari saluran pencernaan menyebabkan kelebihan besi pada tubuh. Peningkatan kadar besi dalam tubuh menyebabkan peningkatan besi bebas yang memicu Radical Oxygen Species (ROS). Lipid peroksida berasal dari asam lemak tak jenuh ganda yang tidak stabil dan terurai membentuk serangkaian kompleks senyawa, yang diantaranya yaitu termasuk senyawa karbonil reaktif dimana yang paling melimpah adalah MDA. Oleh karena itu, pengukuran MDA banyak digunakan sebagai indikator peroksidasi lipid. Di samping itu, resiko kerusakan oksidatif dapat dikurangi oleh antioksidan, salah satu di antara antioksidan yang memiliki potensi tinggi adalah vitamin E yang merupakan vitamin larut lemak. Penelitian ini bertujuan untuk mengkaji penggunaan vitamin E terhadap penurunan kadar MDA pada pasien $\beta$-talasemia mayor anak. Metode penelitian yang digunakan adalah observasional longitudinal 1 kelompok tanpa pembanding untuk mengkaji pengaruh pemberian vitamin E sebagai antioksidan terhadap penurunan kadar MDA pada pasien $\beta$-talasemia mayor anak. Kriteria inklusi dalam penelitian ini yaitu pasien yang bergantung pada transfusi darah, pasien yang menerima hanya 1 jenis iron chelating agent selama periode penelitian, kondisi klinik stabil, setuju dan telah melengkapi informed consent. Di dalam penelitian terdapat variasi kepatuhan minum vitamin E sekali sehari 200 UI selama 1 bulan pada 21 pasien yaitu hanya 11 pasien dari 21 pasien yang mengkonsumsi 30 tablet vitamin E 200 IU (total dosis 6000 IU) dalam 1 bulan penelitian, dan hanya 11 sampel yang dianalisis lebih lanjut. Kadar serum MDA sebelum dan sesudah pemberian vitamin E dan karakteristik pasien dicantumkan sebagai informasi tambahan. Hasil penelitian ini yaitu rata-rata kadar MDA pada pasien $\beta$-talasemia mayor anak sebelum pemberian vitamin E yaitu 1239,4 $\pm 502,55 \mathrm{ng} / \mathrm{mL}$ dan rata-rata kadar MDA sesudah pemberian vitamin E yaitu $786,49 \pm$ $704,88 \mathrm{ng} / \mathrm{mL}(p=0,15)$. Penggunaan vitamin E (Dosis $200 \mathrm{IU}$ sekali sehari selama 1 bulan) belum mampu menurunkan kadar MDA dalam serum darah pasien $\beta$-talasemia mayor anak. (FMI 2017;53:49-55)
\end{abstract}

Kata kunci: $\beta$-talasemia major, Vitamin E, MDA, antioksidan, ROS, peroksidasi lipid

\begin{abstract}
Thalassemia is a hereditary form of anemia that affects the synthesis of hemoglobin. The management of therapy in patients with $\beta$ thalassemia major which patients should receive continuous blood transfusions and increased iron absorption from the digestive tract causes excess iron in the body. This will lead to an increase of free iron level that triggers Radical Oxygen Species (ROS). Increased level of ROS can initiate lipid peroxidation which used as an indicator of oxidative stress in cells and tissues and produce reactive carbonyl, mainly malondialdehyde (MDA). Thus, MDA measurement is widely used as an indicator of lipid peroxidation. On the other hand, the risk of oxidative damage can be reduced by antioxidant, one of them is Vitamin E that is a fat-soluble vitamin

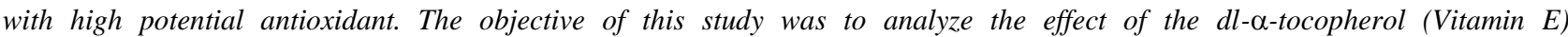
administration on decrease of MDA serum level on pediatric patients with $\beta$-thalassemia major. This was a longitudinal observational study design for one group without comparison was conducted to examine the use of vitamin E to decreased MDA serum level on children patients with $\beta$-thalassemia major. The inclusion criteria were patients who rely on blood transfusions, patients who received only one type of iron chelating agents during the study period, the clinical condition is stable, agrees, and has completed the informed consent. In the course of the study of 21 patients there were variations in patient compliance in taking vitamin E tablet dosage 200 IU once-daily for one month: only 11 out of 21 patients consumed 30 tablets of vitamin E 200 IU (total dose of $6000 \mathrm{IU})$ in the 1-month study, and only data from those 11 samples will be analysed further. MDA serum level was measured pre- and post-administration of vitamin $E$ and patient's characteristics of subjects was obtained for additional information. Pre-administration of vitamin E, serum level of MDA was $1239.4 \pm 502.55 \mathrm{ng} / \mathrm{mL}$ with a range of 216.95 to 2297.3 $\mathrm{ng} / \mathrm{mL}$, whereas in the group post administration of vitamin E. MDA serum level was $786.49 \pm 704.88 \mathrm{ng} / \mathrm{mL}$ with a range of 6.5380 to $1958.6 \mathrm{ng} / \mathrm{mL}$. In conclusion, there was no significant difference in MDA serum level in the group pre-and post-administration of vitamin $E(p=0.15)$. (FMI 2017;53:49-55)
\end{abstract}

Keywords: $\beta$-thalassemia major, Vitamin E, MDA, antioxidant, ROS, lipid peroxidation

Correspondence: Levana Rismayanti, BTN Caruban No. 10 RT/RW 002/004, Desa Gintung Lor Village, Subdistrict Susukan, Cirebon, West Java, Indonesia. Phone:+6281327645103. Email: ranave191@ gmail.com 


\section{INTRODUCTION}

Thalassemia is a hereditary form of anemia that affects the synthesis of hemoglobin. Abnormalities of erythrocytes in thalassemia formed from excessive accumulation of unpaired normal globin chains. $\beta$-thalassemia is the most common inherited single-gene disorders and caused by the 200 mutations in $\beta$-globin gene. Approximately 190 million people worldwide carry the hemoglobinopathies gene and more than 90 million people carry the defective gene that leads to thalassemia. Millions of people, especially in South-east Asia suffer from $\beta$-thalassemia (Das, et al., 2004; Dissayabutra, et al., 2005). World Health Organization (WHO) declare the genetic diversity of the population is reflected in the frequency (carrier) $\beta$-thalassemia in Indonesia which ranged from 5-10\% (World Health Organization, 2013). The prevalence of thalassemia in Indonesia is $0.1 \%$ (Badan Penelitian dan Pengembangan Kesehatan, 2007).

The management of therapy in patients with $\beta$ thalassemia major which patients should receive continuous blood transfusions and increased iron absorption from the digestive tract causes excess iron in the body (Dissayabutra, et al., 2005; Bhagat, et al., 2013). Elevated level of iron in the body causes an increase in free iron that trigger Radical Oxygen Species (ROS). Iron is known to be a catalyst in the formation of ROS, especially hydroxyl radicals $(\mathrm{OH} \bullet)$, which acts as a reagent Fenton. The other Fenton reagents are hemichromes, which is a family of proteins denatured iron from methemoglobin until the complete separation of heme from globin.

The hydroxyl radical is facilitated by membrane bound iron can be very dangerous because it will radically alienated from the antioxidant ability of cells and occurs directly on the membrane lipids and proteins. The hydroxyl radical endanger biochemical substance that eventually oxidize various components including erythrocyte membrane proteins and lipids, causing cellular integrity is damaged, leaking, and cell death (Das, et al., 2004; Dissayabutra, et al., 2005; Rachmilewitz, et al., 2005).

Free radicals-induced oxygen, tissue injury, and severe anemia ( $\mathrm{Hb}$ range of 2-7 g/dl) can speed up multi-organ abnormalities, especially the organ where accumulated the excess iron such as liver, spleen, pancreas, and heart. In addition, increased oxidative stress by a decrease in antioxidant nutrients lead to congestive heart failure which is the highest cause of death in $\beta$ thalassemia major (Bhagat, et al., 2012; Bhagat, et al., 2013).
Several studies have been conducted to examine the effects of antioxidant vitamin $\mathrm{E}$ in reducing the level of oxidants in the body. Prospective double-blind placebocontrolled study conducted by Mahjoub, et al. (2007) suggest that vitamin E $(550 \mathrm{mg} /$ day $)$ was significantly lower erythrocyte membrane lipid per-oxidation and can be useful in the management of patients with $\beta$ thalassemia major. Vitamin E was significantly lower and MDA concentrations in eryth-rocytes membranes were significantly higher in $\beta$-thalassemia patients compared to controls $(\mathrm{P}<0.001)$. In groups that treated with vitamin supplements for 4-weeks, lipid peroxidation rates were significantly reduced after treatment $(\mathrm{P}<0.001)$, but in placebo group there was not significant difference $(\mathrm{P}>0.05)$. The results of the study provide evidence that oral treatment with vitamin $\mathrm{E}$ (550 mg/day), can signifi-cantly reduce lipid peroxidation of erythrocyte mem-branes and could be useful in the management of patients with $\beta$-thalassemia major.

Double blind randomized clinical trial was conducted by Rashidi, et al. (2011) suggest that the level of vitamin $\mathrm{E}$ increased significantly $(\mathrm{P}<0.001)$. Mean Glutathione Peroxidase (GPX) activity decreased significantly $(\mathrm{P}<0.032)$ and a Body Mass Index $(\mathrm{BMI})$ had increase significantly $(\mathrm{P}<0.001)$. The results of this study suggest that $\beta$ thalassemic patients have enhanced oxidative stress and administration of selective antioxidants may preclude oxidative damage. Malondialdehyde, which results from oxidation of polyunsaturated fatty acids (PUFAs), is also present in high amounts in organs of the reticuloendothelial system (RES) of thalassemic patients. MDA is known to cause cross-linking of membrane components, thus increasing $\mathrm{RBC}$ membrane rigidity and decreasing $\mathrm{RBC}$ deformability. Lipid peroxidation plays an important role in RBC removal by the RES. It has been shown to alter membrane phospholipids asymmetry, an important determinant of $\mathrm{RBC}$ recognition by macrophages (Mahjoub, et al., 2007).

In this study want to analyze how much vitamin $\mathrm{E}$ can reduce level of MDA which mostly formed in patients with thalassemia thus prevent organ damage and as information material to strengthen the medication procedures in dr. Soetomo Hospital.

\section{MATERIALS AND METHODS}

This study used longitudinal observational study design one group without comparison to analyze the use of vitamin $\mathrm{E}$ as an antioxidant to decrease MDA level in patients with $\beta$-thalassemia major children. Samples were patients $\beta$-thalassemia major children who under- 
went blood transfusions at the Department of Pediatric Haematology Dr. Soetomo Hospital who met the inclusion criteria. This study used longitudinal observational study designs pre- and post-test with consecutive sampling method. Sampling method used Time Limited Sampling method, during the periode who met inclusion criteria August to September 2015 included as a sample and then be monitored for 1 month. The inclusion criteria were patients who rely on blood transfusions, patients who received only one type of iron chelating agents during the study period, the clinical condition is stable, agrees, and has completed the informed consent.

\section{RESULTS}

There were variations in 21 patients compliance in taking tablets of vitamin E doses of 200 IU q.d. for one month (total tablet 30 tablets or a total dose of $6000 \mathrm{IU}$ ). One patient consumed 2 tablets (vitamin E 200 IU total dose of $400 \mathrm{IU}$ ), one patient consumed 13 tablets (total $2600 \mathrm{IU})$, one patient consumed 15 tablets (3000 IU), 3 patients consumed 21 tablets (4200 IU), one patient consumed 22 tablets (total 4400 IU), 2 patients consumed 26 tablets (5200 IU), one patient consumed 28 tablets (total $5600 \mathrm{IU}$ ), and 11 patients consumed for a full month (30 tablets, total dose of $6000 \mathrm{IU})$. This data showed that by increasing the dose of vitamin $\mathrm{E}$ can reduce level of MDA. This suggested that exposure to doses of vitamin $\mathrm{E}$ is directly equivalent to the amount of decrease in MDA level.

To see the effect of vitamin E to MDA level, we used 11 samples which consumed 30 tablets of vitamin E 200 IU (total dose of $6000 \mathrm{IU}$ ) in one month of the study. Eleven patients with a diagnosis of $\beta$-thalassemia major were analyzed based on the characteristics subjects of the study include age, type of thalassemia, nutritional status, frequency of transfusions per year, $\mathrm{Hb}$ before transfusion, and Ferritin level (Table 1).

Table 1. Characteristics of Subjects

\begin{tabular}{|c|c|c|c|}
\hline Characteristics & $\begin{array}{l}\text { Number } \\
(\mathrm{n}=11)\end{array}$ & $\%$ & Mean \\
\hline \multicolumn{4}{|l|}{ Sex } \\
\hline Male & 6 & 55 & - \\
\hline Female & 5 & 45 & - \\
\hline \multicolumn{4}{|l|}{ Age. years } \\
\hline$<5$ & 2 & 18 & 3 \\
\hline $5-10$ & 7 & 64 & 7 \\
\hline$>10$ & 2 & 18 & 14 \\
\hline \multicolumn{4}{|l|}{ Thalassemia type } \\
\hline Homozygous $\beta$-Thalassemia & 4 & 36 & - \\
\hline$\beta$-Thalassemia/HbE & 7 & 64 & - \\
\hline \multicolumn{4}{|l|}{ Nutritional status } \\
\hline Overweight & 1 & 9 & - \\
\hline Normal & 6 & 55 & - \\
\hline Undernourised & 4 & 36 & - \\
\hline \multicolumn{4}{|l|}{$\begin{array}{l}\text { Transfusion frequency, times per } \\
\text { year }\end{array}$} \\
\hline$<10$ & 1 & 9 & 6 \\
\hline $10-15$ & 10 & 91 & 12 \\
\hline \multicolumn{4}{|l|}{ Pre-transfusion hemoglobin, g/dL } \\
\hline$<6$ & 3 & 27 & 5.2 \\
\hline $6-8$ & 5 & 46 & 6.9 \\
\hline$>8$ & 3 & 27 & 9.0 \\
\hline \multicolumn{4}{|l|}{ Ferritin level, $\mu \mathrm{g} / \mathrm{L}$} \\
\hline$\leq 1000$ & 1 & 9 & 733.81 \\
\hline$>1000$ & 10 & 91 & 3728.0 \\
\hline
\end{tabular}


Table 2. MDA Level Pre-and Post- Administration of Vitamin E

\begin{tabular}{cccccc}
\hline $\begin{array}{c}\text { Subject } \\
\text { Initial Name }\end{array}$ & $\begin{array}{c}\text { Age } \\
(\text { Years })\end{array}$ & $\begin{array}{c}\text { Weight } \\
(\mathrm{kg})\end{array}$ & Height $(\mathrm{cm})$ & $\begin{array}{c}\text { MDA Level Pre- } \\
\text { Administration of } \\
\text { Vitamin E (ng/mL) }\end{array}$ & $\begin{array}{c}\text { MDA Level Post- } \\
\text { Administration of } \\
\text { Vitamin E (ng/mL) }\end{array}$ \\
\hline RF & 7 & 16 & 109 & 962.05 & 1614.6 \\
AC & 8 & 19 & 115 & 1088.8 & 977.09 \\
MM & 14 & 35 & 146 & 1140.6 & 35.509 \\
TA & 5 & 15 & 97 & 1461.0 & 1330.9 \\
RD & 7 & 18 & 110 & 216.95 & 883.71 \\
YOH & 8 & 24 & 118 & 1466.7 & 1280.5 \\
MHA & 4 & 14 & 102 & 2297.3 & 395.65 \\
MAA & 13 & 35 & 145 & 1208.7 & 6.5380 \\
MF & 6 & 16 & 112 & 1295.9 & 158.98 \\
AZ & 8 & 17 & 115 & 977.06 & 1958.6 \\
MYA & 3 & 10 & 90 & 1518.6 & 9.3280 \\
\hline Mean \pm SD & $8 \pm 3$ & $20 \pm 8$ & $114 \pm 17$ & $1239.4 \pm 502.55$ & $786.49 \pm 704.88$ \\
\hline Range & $3-14$ & $10-35$ & $90-146$ & $216.95-2297.3$ & $6.5380-1958.6$ \\
\hline
\end{tabular}

According to the table 1 shows that patients with $\beta$ thalassemia major male was the largest $(55 \%)$ in sex group, the largest type of thalassemia was $\beta$-thalasse$\mathrm{mia} / \mathrm{HbE}(64 \%)$, 5-10 years were the largest $(64 \%)$ in age group, normal nutritional status was the largest (55\%), the largest frequency of transfusion was 10-15 times/year (91\%), the largest hemoglobin level before transfusion were $6-8 \mathrm{~g} / \mathrm{dL}(46 \%)$, and the largest level of Ferritin > 1000 ug/L (91\%).

Pre- and post- administration of vitamin E MDA test for each blood samples from patients in each group were determined using a Competitive ELISA. MDA level pre- and post-administration of vitamin $E$ from each patient can be seen in Table 2. Table 2 shows the administration of vitamin $\mathrm{E}$ in 8 patients $(73 \%)$ of 11 patients $(100 \%)$ can reduce level of serum MDA, but there were some patients who have elevated level of MDA. RF, RD, and AZ (3 patients) did not experience MDA level reduction (27\%). RF (7 years old) had a history of parotitis (7/14), RD patients (6 years old) had a history of urinary tract infection $(+)$ E. coli $(6 / 14)$ and often consume eggs which belonging to the foods with high iron content, and AZ (7 years) had difficulty of eating.

Statistical analyses were used to determine differences in the MDA level pre- and post- administration of vitamin $E$ was paired test $(p=0,15)$ that had meaning the use of vitamin E 200 IU for 1 month in pediatric patients with $\beta$-thalassemia major could not reduce MDA level significantly.

The results of the analysis of several patient characteristics that could be analyzed in the study showed that the group in thalassemia type and hemoglobin concen- tration before transfusion showed no statistically significant differences except for the group of patients with hemoglobin level before transfusion $6-8 \mathrm{~g} / \mathrm{dL}$ had statistically significant differences $(\mathrm{p}<0.05)$.

\section{DISCUSSION}

The entire sample received only one type of iron chelating agents during the study period i.e. Deferipron so there were not cause a large variation in MDA level associated with the presence of the free iron. The national prevalence of thalassemia is $0.1 \%$ so the sample obtained were 21 patients who met the inclusion criteria, but in the implementation of the study of 10 patients not consumed vitamin E regularly (total dose of $6000 \mathrm{IU}$ of vitamin E). The reason of non-complianced besause pediatric patients experien-ced cough and cold condition and he did not take any medication, parents forgot to give the medicine, and children who did not want to take medication because of feeling bored for long term medication.

There were variations of 21 patient compliance in consumed vitamin E. Ten patients consumed less than 30 tablet with a total dose of 400 IU s/d 5600 IU and 11 patients consumed 30 tablets (total dose of 6000 IU), which showed that exposure to doses of vitamin $\mathrm{E}$ equivalent to the number of MDA decreased level.

To see the effect of vitamin $\mathrm{E}$ we used 11 patients who consumed 30 tablets of vitamin E 200 IU (total dose of $6000 \mathrm{IU})$ in one month study. Eleven patients with a diagnosis of $\beta$-thalassemia major were analyzed based on the characteristics that could affect MDA sample. Some of the characteristics that could affect MDA level 
in sample include age, type of thalassemia, nutritional status, frequency of transfusions per year, $\mathrm{Hb}$ before transfusion, and Ferritin level.

In the characteristic subject, patients with $\beta$-thalassemia major male was the largest $(55 \%)$ in sex group, the largest type of thalassemia was $\beta$-thalassemia/HbE (64\%), 5-10 years were the largest (64\%) in age group, normal nutritional status was the largest (55\%), the largest frequency of transfusion was 10-15 times/ year (91\%), the largest hemoglobin level before transfusion were $6-8 \mathrm{~g} / \mathrm{dL}(46 \%)$, and the largest level of Ferritin > $1000 \mathrm{ug} / \mathrm{L}(91 \%)$.

Eleven patients were analyzed further to determine the level of MDA pre- and post- administration of vitamin E by using Competitive ELISA. MDA level pre- and post- administration of vitamin $\mathrm{E}$ each patient can be seen in Table 2 which shows the administration of vitamin $\mathrm{E}$ in 8 patients $(73 \%)$ can reduce MDA serum level, but there were some patients who have elevated MDA level, namely in patients RF, RD, and AZ (3 patients). RF (7 years old) had a history of parotitis (7/14), RD (6 years old) had a history of urinary tract infection (+) E. coli (6/14) and often consumed eggs which have high iron content, and AZ (7 years) experienced trouble eating.

Infection experienced in $\mathrm{RF}$ and $\mathrm{RD}$ is an exogenous stimulus in the production of ROS that can lead to increased MDA level through enzymatic processes in the biosynthesis of thromboxane A2 (TXA2). TXA2 is biologically active metabolite of arachidonic acid formed by the action of thromboxane A2 synthase in prostaglandin endoperoxide or prostaglandin $\mathrm{H} 2$ (PGH 2). PGH2 previously produced by the action of cyclooxygenase in arachidonic acid (AA) (Ayala, et al., 2014). In addition to had a history of infection, RD patients also often consume eggs which havw high iron content. Foods with high iron content should be avoided to reduce the accumulation of iron to avoid receiving continuous blood transfusions too early for patients (Arijanty \& Nasar, 2003). In patients who have difficulty eating (AZ) due to the severity of anemia and enlarge spleen cause decreased appetite, reduced food intake and lead to malnutrition. This nutritional disorder causes increased oxidation of biomolecular and cell injury, triggering the formation of MDA (Fang, et al., 2002; Arijanty \& Nasar, 2003).

This study results MDA level pre- and postadministration of vitamin E. Statistical analyses were used to determine differences in the MDA level pre- and post- administration of vitamin $\mathrm{E}$ was paired t test $(\mathrm{p}=$ 0,15 ) that had meaning the use of vitamin E 200 IU for 1 month in pediatric patients with $\beta$-thalassemia major could not reduce MDA level significantly. The results of this study are supported by previous studies showing that there is no correlation between MDA level with the use of vitamin $\mathrm{E}$ regularly because in the process of sampling were difficult to divide the sample in a balanced proportion between the age group, gender, and other variables so that distribution statistics are spacious which led the research becomes insignificant (Gunarsih, et al., 2012; Saud, 2012).

In contrast to the results above, research conducted by Gultom \& Adhiyanto (2004) which stated that the administration of vitamin $\mathrm{E}$ could reduced MDA level in the red blood cells of thalassemias. In addition, prospective double-blind placebo-controlled study conducted by Mahjoub, et al. (2007), Vitamin E (550 $\mathrm{mg} /$ day) could lower erythrocyte membrane lipid peroxidation significantly and could be useful in the management of patients with $\beta$-thalassemia major. The study supported randomized double blind clinical trial conducted by Rashidi, et al. (2011) ie $\beta$-thalassemia patients experienced an increase in oxidative stress and antioxidants could block the provision of oxidative damage selectively. There were also double-blind placebo controlled randomized clinical trial conducted by Fitrianto, et al. (2014) in pediatric aged 2-14 years with thalassemia major showed that supplementation of vitamin $E$ improved fragility of erythrocytes and hemoglobin level in patients with $\beta$-thalassemia major children by reducing the cross-link between MDA with spectrin of erythrocyte membrane.

The most important antioxidant is vitamin $\mathrm{E}$ because vitamin $\mathrm{E}$ is a main "scavenger" to get rid of free radicals in the cell membrane by inhibiting lipid peroxidation process of cell membrane. The most effec-tive form of tocopherol is $d-\alpha$-tocopherol, because this form can be easily absorbed by the intestine and can last a long time in the tissue (Gultom \& Adhiyanto, 2004).

In this study the factors that could affect MDA level were also analyzed. Factors that could affect MDA level were grouped in the form of subject charac-teristics. To determined differences in MDA level between pre- and post- vitamin $\mathrm{E}$ administration in subject characteristic when MDA level was normally distributed then tested with paired $t$ test $(n \geq 7)$, whereas if MDA level was not normally distributed, then using the Wilcoxon rank marked $(n<7)$. Subject characteristics that could affect MDA level that could be analyzed further were thalassemia type and hemoglobin concentration before transfusion.

Thalassemia type in this research was divided into two variants namely homozygous $\beta$-thalassemia and $\beta$ thalassemia/HbE. $\beta$-thalassemia homozygot patients had 
mean MDA level was higher than MDA level in $\beta$ thalassemia/HbE patients, similar to the result of this study, $\beta$-thalassemia homozygous patients had mean MDA level was higher than MDA level in $\beta$ thalassemia/HbE level, but the result of data analysis were not significant (Gunarsih, et al., 2012). $\beta$-thalassemia/ $\mathrm{HbE}$ based on the pathogenesis of the disease is milder than $\beta$-thalassemia homozygous for patients with $\beta$-thalassemia/HbE be able to compen-sate for anemia than $\beta$-thalassemia homozygous due to the nature of $\mathrm{HbE}$ and mean level of $\mathrm{HbF}$ lower than mean level of $\mathrm{HbF} \beta$-thalasemia homozygous (Fucharoen \& Weatherall, 2012) so that the number of transfusions in patients with thalassemia type $\beta$-thalassemia homozygous were more than thalassemia patients with $\beta$-thalassemia/HbE type so Ferritin and MDA production was higher in patients with $\beta$-thalassemia homozygous (Goswami, et al., 2005). In this study, in addition to the homozygous $\beta$-thalassemia patients had a higher level of MDA than $\beta$-thalassemia/HbE patients, but also had lower level of serum Ferritin, probably because homozygous $\beta$ thalassemia patients had a younger mean age, shorter length of disease, and better nutritional status than thalassemia- $\beta / \mathrm{HbE}$ subjects (Gunarsih, et al., 2012).

In addition to thalassemia type, hemoglobin level before transfusion in patients also analyzed further for there are correlation between hemoglobin level and MDA serum level in thalassemia patients. The lower hemoglobin concentration, the higher MDA level which indicates the role of oxidative stress (Tamam, et al., 2012). Then the results of Tamam, et al., (2012) is supported by the results of the next research that vitamin E supplementation improve erythrocyte fragil-ity and hemoglobin levels in patients with $\beta$-thalassemia major children. However, AlHakeim, et al. (2014) showed the correlation was not statistically significant between $\mathrm{Hb}$ with MDA $(r=0.01)$. In this study showed MDA level decrease after administration of vitamin $\mathrm{E}$ not significant different statistically ( $p>0.05$ ) except for the group of patients with hemoglobin levels before transfusion 6-8 g/dL decreased MDA level were significant different statistically $(p<0.05)$ for the group of patients with hemoglobin levels before transfusion $<6 \mathrm{~g} / \mathrm{dL}$ had mean Ferritin level higher than $\mathrm{Hb}$ level in other groups. In addition, the group of patients with hemoglobin level before transfusion $>8 \mathrm{~g} / \mathrm{dL}$ all patients diagnosed with $\beta$-thalassemia/HbE.

In this study, there are lack in the number of samples because of the prevalence of thalassemia in Indonesia is $0.1 \%$, the sample collection study conducted by consecutive sampling, time of administration of vitamin $\mathrm{E}$ in not long enough, and need to increase the dose of vitamin $\mathrm{E}$ as in research conducted by Mahjoub et al.
(2007) who studied oral treatment with vitamin E (550 $\mathrm{mg} /$ day) for 4 weeks significantly reduced lipid peroxidation of erythrocyte membranes and can be useful in the management of patients with $\beta$-thalassemia major. In addition, there is difficulty in grouping the sample by age group, gender, and other variables because of the limited number of samples.

From the results of this study indicate that the use of vitamin E $200 \mathrm{IU}$ for 1 month in pediatric patients with $\beta$-thalassemia major did not reduce MDA level statistically significant $(p=0.15)$, but clinically there is a reduction trend in MDA level in patients who regularly use vitamin E $200 \mathrm{IU}$ for 1 month. Based on the characteristics of the patients, the use of vitamin $E$ as an antioxidant in patients with $\beta$-thalassemia major with considering the optimal dose of vitamin $E$ that could reduce MDA level clinically significant.

\section{CONCLUSION}

The use of vitamin E 200 IU for 1 month in patients with $\beta$-thalassemia major child did not reduce MDA level statistically significant $(\mathrm{p}=0.15)$, but clinically there was a reduction trend in the MDA level in patients who regularly use vitamin E 200 IU for 1 month. Based on the results of the study was advised to use vitamin $\mathrm{E}$ as an antioxidant in patients with $\beta$-thalassemia major with considering the optimal dose of vitamin $\mathrm{E}$.

\section{REFERENCES}

AlHakeim, H. K., Auda, F. M. \& Ali, B. M., 2014. Lack of Correlation between Nonlabile Iron Parameters, Total Carbonyl, and Malondialdehyde in Major Thalassemia. Journal of Clinical Biochemis-try and Nutrition, Volume 55(3), p. 203-206.

Arijanty, L. \& Nasar, S. S., 2003. Masalah Nutrisi pada Thalassemia. Sari Pediatri, Volume 5, pp. 21-26.

Ayala, A., Muñoz, M. F. \& Argüelles, S., 2014. Lipid Peroxidation: Production, Metabolism, and Signal-ing Mechanisms of Malondialdehyde and 4-Hydroxy-2Nonenal. Oxidative Medicine and Cellular Longevity, Volume 2014, pp. 1-31.

Badan Penelitian dan Pengembangan Kesehatan, 2007. Riset Kesehatan Dasar. Jakarta: Departemen Kesehatan Republik Indonesia.

Bhagat, S. S. et al., 2012. A Study on the Biomarkers of Oxidative Stress: the Effects of Oral Therapeutic Supplementation on the Iron Concentration and the Product of Lipid Peroxidation in B Thalassemia Major. Journal of Clinical and Diagnostic Research, Volume 6, pp. 1144-1147. 
Bhagat, S. S. et al., 2013. Attenuation of Serum Ferritin and Iron Burden by Intake of Antioxidants in B Thalassemia Major. Indian Journal Physiology Pharmacology, Volume 57(2), p. 189-194.

Das, N., Chowdhury, T. D., Chattopadhyay, A. \& Datta, A. G., 2004. Attenuation of Oxidative Stress-Induced Changes in Thalassemic Erythrocytes by Vitamin E. Polish Journal Pharmacology, Volume 56, pp. 85-96.

Dissayabutra, T., Tosukhowong, P. \& Seksan, P., 2005. The Benefits of Vitamin $\mathrm{C}$ and Vitamin $\mathrm{E}$ in Children with $\beta$-thalassemia with High Oxidative Stress. Journal of The Medical Association of Thailand, Volume 88(Suppl 4), pp. S317-21.

Fang, Y.-Z., Yang, S. \& Wu, G., 2002. Free Radicals, Antioxidants, and Nutrition. Nutrition, Volume 18, p. 872-879.

Fitrianto, A., Tamam, M. \& Widyastiti, N. S., 2014. Vitamin E Effect on Osmotic Fragility in B Thalassemia Major. Paediatrica Indonesiana, Volume 54 , pp. 280-3.

Fucharoen, S. \& Weatherall, D. J., 2012. The Hemoglobin E Thalassemias. Cold Spring Harbor Perspectives in Medicine, Volume 2, p. a011734.

Goswami, K., Ghosh, S., Bandyopadhyay, M. \& Mukherjee, K., 2005. Iron Store and Free Radicals in Thalassemia. Indian Journal of Clinical Biochemistry, Volume 20(2), pp. 192-194.

Gultom, F. \& Adhiyanto, C., 2004. Efek Pemberian Antioksidan Tokoferol Alfa terhadap Membran Sel
Darah Merah Talasemia. Indonesian Journal of Dentistry, Volume 11(2), pp. 71-72.

Gunarsih, A., Amalia, P. \& Boediman, I., 2012. Variables Associated with Malondialdehyde Level in Thalassemia Major Patients. Paediatrica Indonesiana, Volume 52(3), pp. 125-131.

Mahjoub, S., Tamaddoni, A., Nikoo, M. Z. \& Moghadamnia, A. A., 2007. The Effects of BCarotene and Vitamin E on Erythrocytes Lipid Peroxidation in B-Thalassemia Patients. Journal of Research in Medical Sciences, Volume 12(6), pp. S317-S321.

Rachmilewitz, E. A. \& Giardina, P. J., 2011. How I Treat Thalassemia. Blood Journal, Volume 118, pp. 3479-3488.

Rashidi, M. et al., 2011. Effects of Vitamin E and Zinc Supplementation on Antioxidants in B Thalassemia Major Patients. Iranian Journal of Pediatrics, Volume 21(1), pp. 8-14.

Saud, A. M., 2012. Molecular and Biochemical Study on $\beta$-thalassemia Patients in Iraq. Thesis.

Tamam, M. et al., 2012. Hubungan antara Stres Oksidatif dengan Kadar Hemoglobin pada Penderita Thalassemia/Hbe. Jurnal Kedokteran Brawijaya, Volume 27(1), pp. 38-42.

World Health Organization, 2013. Birth Defects In South-east Asia A Public Health Challenge. New Delhi: World Health Organization. 